\title{
Genetic Analysis of Candida albicans Morphological Mutants
}

\author{
By ROSALINA POMÉS, CONCEPCIÓN GIL AND CÉSAR NOMBELA* \\ Departamento de Microbiologia, Facultad de Farmacia, Universidad Complutense, \\ 28040 Madrid, Spain
}

(Received 18 December 1984; revised 18 March 1985)

\begin{abstract}
In contrast to some other strains, Candida albicans 1001 gave rise, upon UV irradiation, to mutants displaying a 'rough colony' morphology associated with a permanent alteration in morphogenesis which determined growth of the cells mostly as pseudohyphae. One of these mutants, C. albicans $1001 \mathrm{FR}$, could form sectored (rough/smooth) colonies spontaneously, and with increasing frequency by treatment with mild UV doses $\left(32-64 \mu \mathrm{J} \mathrm{mm}^{-2}\right)$. Rough sectors corresponded to stable 'rough-filamentous' strains which never segregated smooth strains. On the other hand, smooth sectors consisted mainly of yeast cells which could occasionally revert to a rough-filamentous phenotype. We suggest that $C$. albicans 1001 is heterozygous for some gene involved in the control of morphogenesis, and that the described mutants should be of help in the characterization of the genetic control of dimorphism in $C$. albicans.
\end{abstract}

\section{INTRODUCTION}

Candida albicans is an opportunistic pathogenic yeast that causes different types of human infections of which there has been an increasing incidence in recent years. The well-known capacity of the oval yeast cell to give rise to a typical fungal mycelium represents an interesting differentiation phenomenon. The role of the yeast and mycelial forms in pathogenicity and, therefore, the relevance of dimorphism to virulence of the organism, have been extensively studied (Odds, 1979).

Much information exists regarding the environmental factors that control the yeast-tomycelium transition (Lee et al., 1975; Mitchell \& Soll, 1979; Manning \& Mitchell, 1980a; Mattia et al., 1982), and several studies have also been made concerning the biochemical (Chiew et al., 1980; Sullivan et al., 1983) and antigenic differences between the two types of cells (Chattaway et al., 1968, 1976; Svedsen \& Axelsen, 1972; Manning \& Mitchell, 1980 b, c) as well as the cytology of the process (Soll \& Mitchell, 1983; Gow \& Gooday, 1984). However, a deeper understanding of the biology and pathogenicity of $C$. albicans has been hampered by the difficulties in carrying out genetic analysis in this species. It has been suggested that most of the currently isolated C. albicans strains are diploid (Olaiya \& Sogin, 1979; Riggsby et al., 1982) and, although contested (Sarachek, 1983), this is now widely accepted. Mitotic recombination, induced by mild UV treatment, has been used to follow the segregation of many alleles, through the formation of sectored colonies, and has provided a means for the genetic characterization of many mutants and variants (Whelan et al., 1980; Whelan \& Magee, 1981; Whelan \& Soll, 1982). Genetic studies in C. albicans are also taking advantage of spheroplast fusion methodology to induce parasexual recombination (Kakar et al., 1983; Poulter et al., 1981).

Of particular interest would be the isolation of mutants affected in dimorphism and the identification of genes involved in the control of the morphological transition. In this communication we describe the genetic characterization of $C$. albicans morphological mutants which grew permanently as filaments of pseudomycelial appearance. 


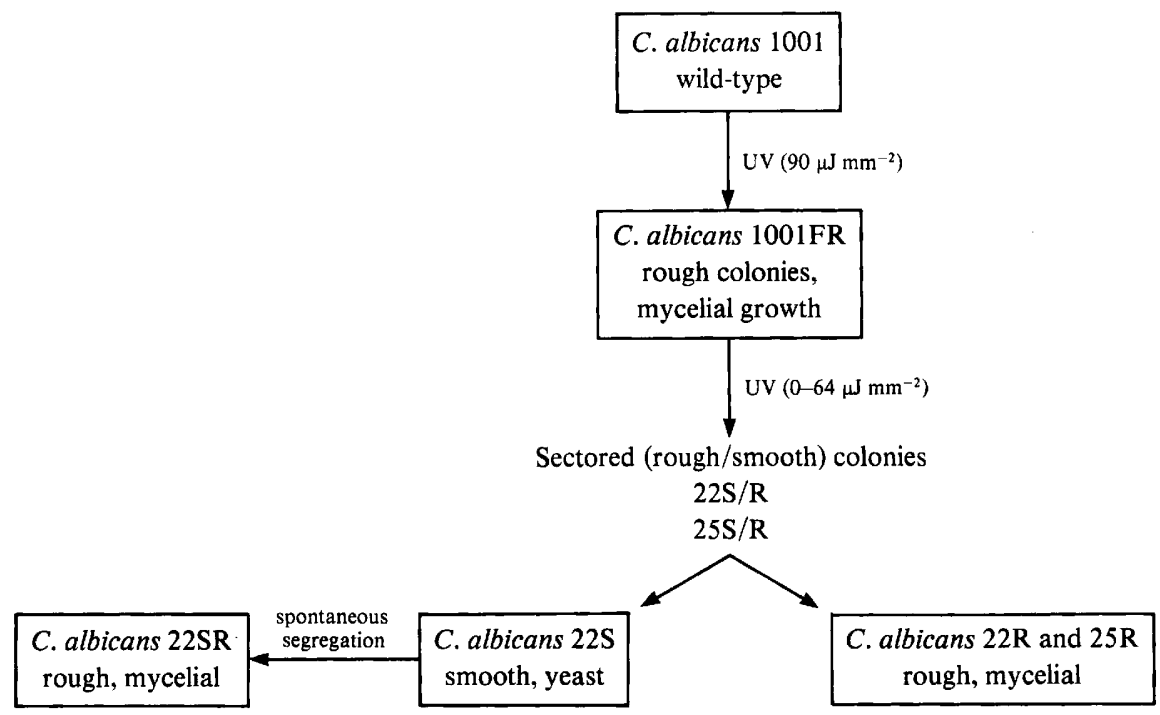

Fig. 1. Strains of $C$. albicans used in this analysis. 22R and 25R were rough segregants which appeared in sectored colonies. $22 \mathrm{~S}$ was a smooth segregant from a sectored colony which could segregate rough strains. 22SR was a rough segregant, derived from $22 \mathrm{~S}$, which appeared as an isolated non-sectored colony. See text for details and Fig. 2 for colonial and cell morphologies.

\section{METHODS}

Organisms. C. albicans 1001, a wild-type strain, was obtained from the Spanish Type Culture Collection (Department of Microbiology, Faculty of Biology, University of Valencia, Spain). The mutant strains described in this paper were derived from C. albicans 1001 as shown in Fig. 1. C. albicans $\mathrm{RC} 1$ and $\mathrm{RC} 2$ were isolated from cases of systemic candidosis by A. Sánchez-Sousa (Hospital Ramón y Cajal, Madrid, Spain). C. albicans 256w $\left(\mathrm{Met}^{-}\right.$) was kindly supplied by W. Whelan (NIH, Bethesda, Md., USA). All strains obtained from the Culture Collection and from other laboratories were confirmed to belong to the species $C$. albicans by germ tube, chlamydospore and sugar assimilation tests under standard conditions (Silva-Hutner \& Cooper, 1980).

Media. For long-term maintenance, strains were stored in sterile $50 \%(\mathrm{v} / \mathrm{v})$ glycerol at $-20^{\circ} \mathrm{C}$. For shorter periods, they were maintained on slants of YED agar containing $(\mathrm{w} / \mathrm{v}) 2 \%$ glucose and $1 \%$ yeast extract, at $4{ }^{\circ} \mathrm{C}$. Plates of YED agar were used for all the experiments.

$U V$ irradiation. Cells grown for $48 \mathrm{~h}$ were suspended in sterile distilled water and appropriate dilutions were plated on YED agar to give a final count of $2 \times 10^{2}$ to $2 \times 10^{3}$ c.f.u. per plate, depending on the UV dose to be used. The plates were irradiated in the dark, with a UV Atom-70 UV lamp for periods of 20 to $120 \mathrm{~s}$ at a dose rate of $1.6 \mu \mathrm{J} \mathrm{mm}^{-2} \mathrm{~s}^{-1}$ measured with a UV intensity meter (Ultraviolet Products). The irradiated plates and appropriate unirradiated control plates were incubated at $28^{\circ} \mathrm{C}$ for $48 \mathrm{~h}$.

\section{RESULTS}

After UV irradiation $\left(90 \mu \mathrm{J} \mathrm{mm}^{-2}\right)$ of $C$. albicans 1001 , we were able to select a mutant, namely $C$. albicans $1001 \mathrm{FR}$, on the basis of a 'rough' colonial morphology. These rough colonies (Fig. 2a) consisted of branched or unbranched filamentous forms (Fig. 2d). Microscopic examination of many preparations of these cells, grown under different conditions, revealed that the filaments were long, pleomorphic and with occasional constrictions, thus having the appearance of what are currently described as pseudohyphae. However, we also occasionally observed long unconstricted filaments with some septa, which were closer to hyphal or intermediate (between hyphal and pseudohyphal) forms. This morphology was maintained when the mutant strain was grown at $37^{\circ} \mathrm{C}$ in serum or in a medium containing $0.1 \%$ yeast extract and $0.01 \%$ proline (M. Molina, personal communication), both of which support hyphal growth of the parent strain. The colonial and cellular morphologies of this mutant were thus clearly distinguishable from those of the wild-type. 

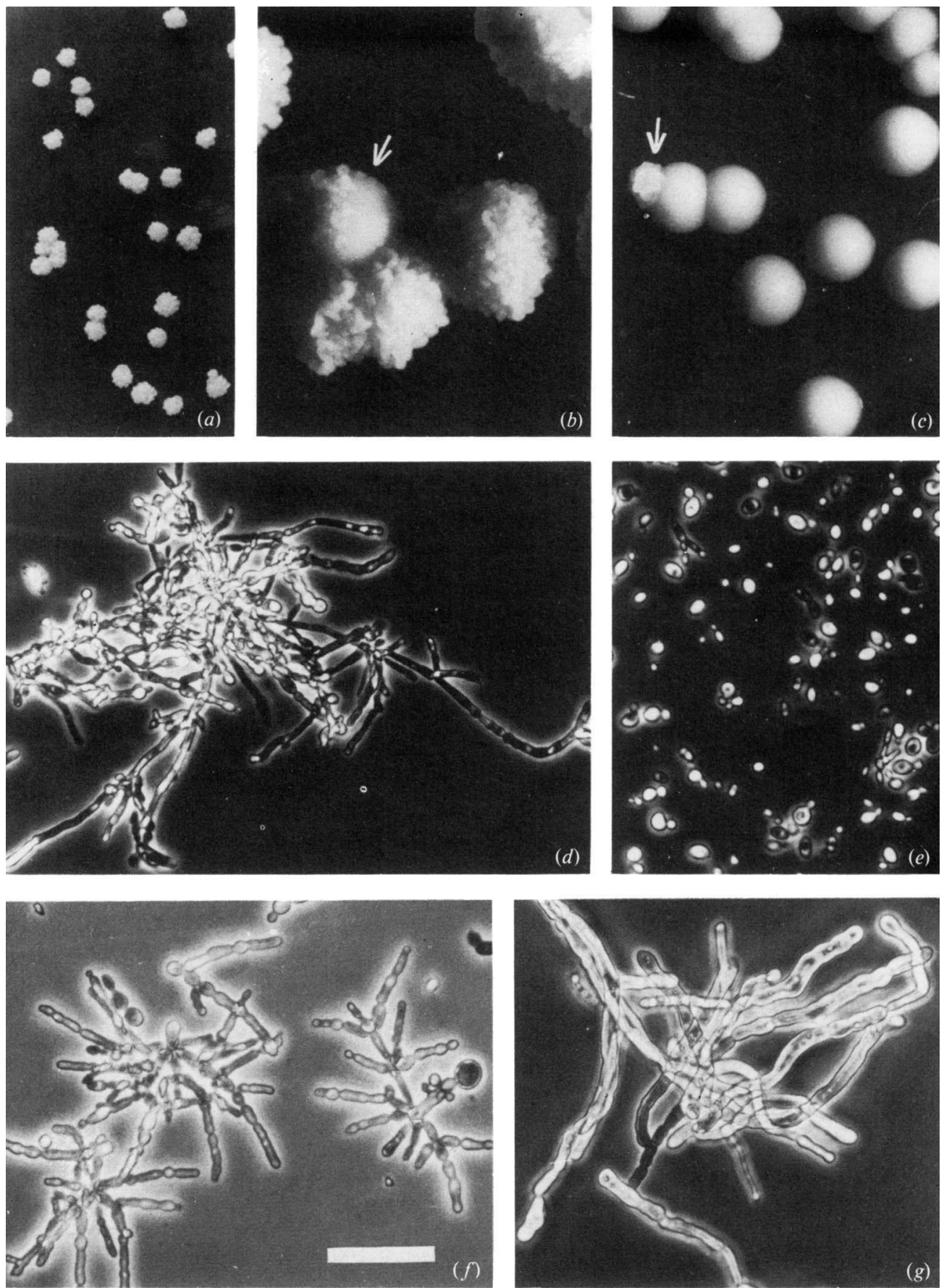

Fig. 2. Colonial and cell morphologies of different strains of $C$. albicans. (a) Rough colonies of $C$. albicans 1001FR. (b) A smooth sector in a colony of $C$. albicans 1001 FR. (c) Smooth colonies of $C$. albicans 22S; a rough segregant can also be observed. $(d-g)$ Phase-contrast micrographs (the bar represents $40 \mu \mathrm{m})$ of strain $1001 \mathrm{FR}(d)$, strain $22 \mathrm{~S}(e)$, a rough mutant obtained by irradiation $\left(160 \mu \mathrm{J} \mathrm{mm}^{-2}\right)$ of $C$. albicans $1001(\mathrm{f})$, and strain 22SR $(g)$. 
Table 1. Frequency of 'rough-colony' mutants induced by UV treatment of different strains of C. albicans

\begin{tabular}{lccccc} 
Strain & $\begin{array}{c}U V \text { dose } \\
\left(\mu \mathrm{J} \mathrm{mm}^{-2}\right)\end{array}$ & $\begin{array}{c}\text { No of } \\
\text { colonies screened }\end{array}$ & $\overbrace{\text { Total }}^{\text {Rough colonies* }}$ & Percentage & $\begin{array}{c}\text { Percentage } \\
\text { survival }\end{array}$ \\
1001 & 0 & 12000 & 0 & 0 & 100 \\
& 32 & 1885 & 1 & $0 \cdot 05$ & $79 \cdot 3$ \\
& 64 & 1982 & 6 & $0 \cdot 3$ & 87 \\
& 96 & 435 & 6 & $1 \cdot 4$ & $18 \cdot 1$ \\
$\mathrm{RC} 1$ & 160 & 4402 & 12 & $0 \cdot 27$ & 14 \\
$\mathrm{RC2}$ & 192 & 6010 & 0 & 0 & $8 \cdot 5$ \\
$265 w$ & 64 & 921 & 0 & 0 & $3 \cdot 7$ \\
& \multicolumn{4}{c}{ * Rough colonies never appeared as sectors. }
\end{tabular}

Table 2. Effect of UV irradiation on the formation of 'smooth' and 'rough' segregants from different strains of C. albicans

\begin{tabular}{|c|c|c|c|c|c|c|c|}
\hline \multirow[b]{2}{*}{ Strain* } & \multirow[b]{2}{*}{$\begin{array}{l}\text { Colonial } \\
\text { phenotype }\end{array}$} & \multirow[b]{2}{*}{$\begin{array}{l}\text { UV dose } \\
\left(\mu \mathrm{J} \mathrm{mm}^{-2}\right)\end{array}$} & \multirow[b]{2}{*}{$\begin{array}{c}\text { No. of } \\
\text { colonies screened }\end{array}$} & \multicolumn{3}{|c|}{ Percentage of $\nmid$ : } & \multirow[b]{2}{*}{$\begin{array}{l}\text { Percentage } \\
\text { survival }\end{array}$} \\
\hline & & & & R/S & $\mathbf{S}$ & $\mathbf{R}$ & \\
\hline 1001FR & $\mathbf{R}$ & $\begin{array}{r}0 \\
32 \\
64\end{array}$ & $\begin{array}{l}1136 \\
1068 \\
1280\end{array}$ & $\begin{array}{l}0.35 \\
0.56 \\
1.2\end{array}$ & $\begin{array}{l}0 \\
0 \\
0\end{array}$ & $\begin{array}{l}99.65 \\
99.44 \\
98.8\end{array}$ & $\begin{array}{r}100 \\
94 \\
75\end{array}$ \\
\hline $22 \mathrm{R}$ & $\mathbf{R}$ & $\begin{array}{r}0 \\
32\end{array}$ & $\begin{array}{l}5732 \\
5240\end{array}$ & $\begin{array}{l}0 \\
0\end{array}$ & $\begin{array}{l}0 \\
0\end{array}$ & $\begin{array}{l}100 \\
100\end{array}$ & $\begin{array}{l}100 \\
91 \cdot 4\end{array}$ \\
\hline $25 \mathrm{R}$ & $\mathbf{R}$ & $\begin{array}{r}0 \\
32\end{array}$ & $\begin{array}{l}2303 \\
2786\end{array}$ & $\begin{array}{l}0 \\
0\end{array}$ & $\begin{array}{l}0 \\
0\end{array}$ & $\begin{array}{l}100 \\
100\end{array}$ & $\begin{array}{c}100 \\
91 \cdot 3\end{array}$ \\
\hline $22 \mathrm{~S}$ & $\mathbf{S}$ & 0 & 2560 & $0 \cdot 35$ & $98 \cdot 4$ & $1 \cdot 1$ & 100 \\
\hline 22SR & $\mathbf{R}$ & $\begin{array}{r}0 \\
32\end{array}$ & $\begin{array}{l}1647 \\
1758\end{array}$ & $\begin{array}{l}0.5 \\
0.34\end{array}$ & $\begin{array}{l}0.8 \\
1\end{array}$ & $\begin{array}{l}98 \cdot 7 \\
98 \cdot 6\end{array}$ & $\begin{array}{c}100 \\
98.6\end{array}$ \\
\hline
\end{tabular}

* The origin of each strain is indicated in Fig. 1.

$+\mathrm{R} / \mathrm{S}$, sectored rough/smooth colonies; $\mathrm{S}$, smooth colonies; $\mathrm{R}$, rough colonies.

Irradiation of $C$. albicans 1001 at doses up to $96 \mu \mathrm{J} \mathrm{mm}^{-2}$ induced mutations which determined rough colonial morphology with increasing frequencies (Table 1). In all cases, rough colonies consisted of filamentous forms (Fig. $2 f$ ), again very different from the typical, oval, wild-type cells. In contrast, no rough mutants were induced upon irradiation of other strains (Table 1). In view of the results shown below, it is remarkable that none of the rough colonies obtained from C. albicans 1001 was sectored, but all of them appeared as isolated rough colonies.

In order to study the stability of the rough-filamentous phenotype in $C$. albicans 1001FR, suspensions of cells from single colonies were plated on YED agar, UV irradiated and screened for segregants with different colonial morphologies. Sectored colonies, with a rough and a smooth portion (Fig. $2 b$ ), were always detected. Smooth segregants appeared only as sectors and never as whole colonies. This segregation occurred spontaneously and with increasing frequency (Table 2) upon UV irradiation up to $64 \mu \mathrm{J} \mathrm{mm}^{-2}$.

Rough and smooth segregants from sectored colonies were separated to compare their properties with those of the parental strain C. albicans 1001FR (Fig. 1). Rough segregants maintained the rough-filamentous phenotype, indistinguishable from the phenotype of the parental strain. However, as shown for strains $22 \mathrm{R}$ and $25 \mathrm{R}$, they no longer segregated smooth strains, either spontaneously or upon UV treatment (Table 2). Thus, the rough-filamentous phenotype was stably maintained in these rough segregants. On the other hand, the cellular morphology of smooth segregants was very similar to that of the wild-type $C$. albicans 1001 . Essentially oval yeast cells together with some aberrant enlarged forms were observed by phasecontrast microscopy of preparations from smooth colonies (Fig. $2 c, e$ ). However, they were 
different from the wild-type because they could give rise to rough segregants which appeared spontaneously either as sectors (Fig. 2c) or as single colonies (Table 2, strain 22S). The phenotypic instability of these types of rough segregants was also clear, as they could again revert to smooth colonies or sectors with significant frequency (Table 2, strain 22SR). These results were reproducible when the experiments were repeated with the same strains and led to the same conclusions when other segregants of the same type were characterized.

\section{DISCUSSION}

We still lack a comprehensive model that could account for all the observations and explain the cellular controls that are operative in morphogenesis of $C$. albicans. Even concepts such as 'germ-tube formation', which are currently used, seem to have many limitations. A variety of media and conditions are used to induce mycelium formation (Odds, 1979); this can be achieved by inoculating starved yeast cells into fresh nutrient medium, but often the method employed consists in incubating yeast cells on media of very limited nutrient concentration, which are very different from those needed for fungal spore germination. In this regard, studies that postulate the existence of a morphogenic autoregulatory substance (MARS) (Hazen \& Cutler, 1979, $1983 a, b)$ are relevant. Although that work requires further substantiation, it would imply that yeast growth takes place because mycelium formation is usually repressed under conditions of excess nutrient supply or in the absence of an inducer of filamentation. This repression also occurs in highly concentrated cell suspensions.

The isolation of mutants altered in the functions that regulate dimorphism in C. albicans would make a substantial contribution towards both clarification of the basis of dimorphism and the detailed comparison between different forms, especially if those mutants were amenable to genetic analysis.

To our knowledge, the results reported here represent the first description of $C$. albicans morphological mutants that can be analysed by means of phenotypic segregation in sectored colonies. In contrast to other strains, $C$. albicans 1001 gave rise to morphological mutants in which a permanent pseudomycelial appearance was associated with a rough colonial morphology. Our mutants seem to be different from the pseudomycelial variant described several years ago (Nickerson \& Chung, 1954; Ward \& Nickerson, 1957; Nickerson, 1963). This variant appeared spontaneously and its morphology was affected by the presence of a diffusible substance produced by cultures of the wild-type, which seemed to be cysteine. Neither this amino acid nor any diffusible substance released by the wild-type cells had any effect on the morphology of our mutants (data not shown). Similarly, the properties of a minute rough variant, derived from an adenine auxotroph, that was described by Ireland \& Sarachek (1968, $1969 a, b)$ differ from those of our mutants. In contrast to this variant, our mutants formed large colonies, did not revert to the parental strain and the expression of their phenotypes was not dependent on the culture medium. The isolation of other types of spontaneous rough variants has also been documented (Vogel \& Sponcler, 1970). However, their possible relationship with the mutants described in this paper is not apparent. Our mutants were induced by mutagenic treatment and their most significant aspect is the correlation of the colonial morphology with the permanent alteration of their cellular morphology. We have even observed some other types of different rough mutants which consisted of yeast cells deficient in filamentation (unpublished observations).

Given that $C$. albicans is diploid we conclude that $C$. albicans 1001 could be heterozygous for some gene $(Y)$ involved in the control of morphogenesis. We postulate that the genetic constitution of this strain was $Y / y_{1}$ and upon irradiation it changed to $y_{2} / y_{1}$ in C. albicans 1001FR, with a phenotype of pseudomycelial growth and rough colonial morphology. According to our hypothesis $y_{1}$ and $y_{2}$ must be two different mutant alleles of the $Y$ gene, in view of the capacity of C. albicans 1001 FR to give rise to sectored rough/smooth colonies. Several events that could lead to sectoring are usually considered to take place upon mitosis. These are crossing over, non-disjunction and gene conversion (Whelan et al., 1980; Crandall, 1983). Our results do not enable us to establish with certainty which of these could be operative in this case. 
However, it is clear that rough segregants stably maintained the rough-filamentous phenotype. Hence, it may be concluded that they are either homozygous for one of the mutant alleles or monosomic.

The situation with smooth segregants is more complicated. Although the corresponding colonies consisted mostly of yeast cells, some aberrant forms were also present and therefore their phenotype was different from that of the wild-type $C$. albicans 1001 . On the other hand, they gave rise to rough segregants that behaved similarly to $C$. albicans $1001 \mathrm{FR}$. It is tempting to speculate that gene $Y$ could be involved in repression of mycelium formation during yeast growth. In that case, one could postulate that some mutant alleles could be partially functional, and determine a wild-type phenotype only under conditions of homozygosity. Smooth segregants could be homozygous for one of the two putative mutant alleles $y_{1}$ and $y_{2}$.

Although other explanations are possible, our interpretation is at least a useful working hypothesis that should enable further characterization of mutants. Furthermore, the possibility of achieving stability of the rough-filamentous phenotype by spontaneous or by mild UV induced segregation facilitates the comparison between the mutants described. The use of techniques such as parasexual recombination through protoplast fusion should contribute to establishing the genotype of these strains, and their characterization by techniques of gene cloning is also under consideration.

This investigation was aided by grants from Comisión Asesora de Investigación Científica y Técnica (CAICYT) and Fondo de Investigaciones Sanitarias de la Seguridad Social (FISSS). C. G. received a fellowship from FISSS.

\section{REFERENCES}

Chattaway, F. W., Holmes, M. R. \& Barlow, A. J. E. (1968). Cell wall composition of the mycelial and blastospore forms of Candida albicans. Journal of General Microbiology 51, 367-376.

Chattaway, F. W., Shenolikar, S., O'Reilly, J. \& BARLOW, A. J. E. (1976). Changes in the cell surface of the dimorphic forms of Candida albicans by treatment with hydrolytic enzymes. Journal of General Microbiology 95, 335-347.

Chiew, Y. Y., Shepherd, M. G. \& Sullivan, P. A. (1980). Regulation of chitin synthesis during germtube formation in Candida albicans. Archives of Microbiology 125, 97-104.

Crandall, M. (1983). UV-induced mitotic co-segregation of genetic markers in Candida albicans: evidence of linkage. Current Genetics 7, 167-173.

Gow, N. A. R. \& GoodAY, G. W. (1984). A model for the germ tube formation and mycelial growth form of Candida albicans. Sabouraudia 22, 137-143.

Hazen, K. C. \& Cutler, J. E. (1979). Autoregulation of germ tube formation by Candida albicans. Infection and Immunity 24, 661-666.

HAzen, K. C. \& CUTLER, J. E. (1983a). Effect of cobalt and morphogenic autoregulatory substance (MARS) on morphogenesis of Candida albicans. Experimental Mycology 7, 182-187.

HAZEN, K. C. \& CUTLER, J. E. (1983b). Isolation and purification of morphogenic autoregulatory substance produced by Candida albicans. Journal of Biochemistry 94, 777-783.

IRELAND, R. \& SARACHEK, A. (1968). A unique minuterough colonial variant of Candida albicans. Mycopathologia 35, 346-360.

IRELAND, R. \& SARACHEK, A. (1969a). Induction and selection of the minute-rough (MR) colonial variant of Candida albicans. Mycopathologia 37, 377-392.
IRELAND, R. \& SARACHEK, A. (1969b). Reversion of the MR variant of Candida albicans. Canadian Journal of Microbiology 15, 1051-1054.

Kakar, S. N., Partridge, R. M. \& Magee, P. T. (1983). A genetic analysis of Candida albicans: isolation of a wide variety of auxotrophs and demonstration of linkage and complementation. Genetics 104, 241-255.

LeE, K. L., BuCKLey, H. R. \& CAMPbell, C. C. (1975). An amino acid liquid synthetic medium for the development of mycelial and yeast forms of Candida albicans. Sabouraudia 13, 148-153.

MANNing, M. \& Mitchell, T. G. (1980a). Strain variation and mycelial phase Candida albicans in low-sulfate, synthetic medium. Journal of Bacteriology 142, 714-719.

Manning, M. \& Mitchell, T. G. (1980b). Morphogenesis of Candida albicans and cytoplasmic proteins associated with differences in morphology, strain or temperature. Journal of Bacteriology 144, 258273.

Manning, M. \& Mitchell, T. G. $(1980 c)$. Analysis of cytoplasmic antigens of the yeast and mycelial phases of Candida albicans by two-dimensional electrophoresis. Infection and Immunity 30, 484495.

mattia, E., Carruba, G., Angiolella, L. \& CASsONe, A. (1982). Induction of germ tube formation by $N$-acetyl-D-glucosamine in Candida albicans. Uptake of inducer and germinative response. Journal of Bacteriology 152, 555-562.

Mitchell, L. H. \& SolL, D. R. (1979). Commitment to germ tube or bud formation during release from stationary phase in Candida albicans. Experimental Cell Research 120, 167-179. 
NiCKerson, W. J. (1963). Symposium on biochemical bases of morphogenesis in fungi. Bacteriological Reviews 27, 305-325.

Nickerson, W. J. \& Chung, C. W. (1954). Genetic block in the cellular division mechanism of a morphological mutant of a yeast. American Journal of Botany 41, 114-120.

OdDs, F. C. (1979). Candida and Candidosis. Leicester: Leicester University Press.

OlaiYA, A. F. \& Sogin, S. J. (1979). Ploidy determination of Candida albicans. Journal of Bacteriology 140 , 1043-1049.

Poulter, R., Jeffery, K., Hubbard, M. H., ShepHERD, M. G. \& Sullivan, P. A. (1981). Parasexual genetic analysis of Candida albicans by spheroplast fusion. Journal of Bacteriology 146, 833-840.

Riggsby, W.S., Torres-BauZa, L. J., WILlis, J. W. \& TownEs, T. M. (1982). DNA content, kinetic complexity and the ploidy question in Candida albicans. Molecular and Cellular Biology 2, 853862.

SARACHEK, A. (1983). Recombinogenic activity of nalidixic acid for artificial hybrids but not for natural strains of Candida albicans: evidence for the monoploidy of natural strains. Zeitschrift für allgemeine Mikrobiologie 23, 385-391.

Sillva-HutNer, M. \& COOPER, B. H. (1980). Yeasts of medical importance. In Manual of Clinical Microbiology, 3rd edn, pp. 562-576. Edited by E. H. Lennette, A. Balows, W. J. Hausler, Jr \& J. P. Truant. Washington, DC: American Society for Microbiology.
Soll, D. R. \& Mitchell, L. H. (1983). Filament ring formation in the dimorphic yeast Candida albicans. Journal of Cell Biology 96, 486-493.

Sullivan, P. A., Chiew, Y. Y., Molloy, C., TempleTON, M. D. \& SHEPHERD, M. G. (1983). An analysis of the metabolism and cell wall composition of Candida albicans during germ-tube formation. Canadian Journal of Microbiology 29, 1514-1525.

SVEDSEN, P. J. \& AXELSEN, N. H. (1972). A modified antigen-antibody crossed electrophoresis characterizing the specificity and titre of human precipitins against Candida albicans. Journal of Immunological Methods 1, 169-176.

VoGel, R. A. \& SPONCLER, R. S. (1970). The study and significance of colony dissociation in Candida albicans. Sabouraudia 7, 273-278.

WARD, J. M. \& NiCKerson, W. J. (1958). Respiratory metabolism of normal and divisionless strains of Candida albicans. Journal of General Physiology 41, 703-724.

Whelan, W. L. \& MageE, P. T. (1981). Natural heterozygosity in Candida albicans. Journal of Bacteriology 145, 896-903.

Whelan, W. L. \& Soll, D. R. (1982). Mitotic recombination in Candida albicans: recessive lethal alleles linked to a gene required for methionine synthesis. Molecular and General Genetics 187, 477485.

Whelan, W. L., Partridge, R. M. \& Magee, P. T. (1980). Heterozygosity and segregation in Candida albicans. Molecular and General Genetics 180, $107-$ 113. 